\title{
STUDY OF THE YEAST STRAIN INFLUENCE AND THE ALCOHOLIC FERMENTATION CONDITIONS ON THE HIGHER ALCOHOLS AND ALDEHYDES CONTENT IN GAMZA WINES
}

\author{
Tatyana YONCHEVA ${ }^{1} \quad$ Hristo SPASOV $^{2}$ \\ Georgi KOSTOV ${ }^{2}$
}

\begin{abstract}
The influence of temperature and inoculum amount of yeast culture on the ability of the strains Saccharomyces cerevisiae Badachoni and Saccharomyces cerevisiae 24-6 to synthesize higher alcohols and aldehydes was studied. Yeast showed the highest fermentation activity at a temperature of $28^{\circ} \mathrm{C}$. Neural networks had been applied and mathematical models were derived, describing with high accuracy the experimental data on the change of the total amount of higher alcohols and aldehydes in the fermentation process depending on the conditions. The higher alcohols ratio had increased during the process. The Badachoni strain revealed better ability to synthesize the studied metabolite as compared to the 24-6 strain. The Badachoni had produced the greatest amount of higher alcohols when the process occurred at $28^{\circ} \mathrm{C}$, whereas the 24-6 at $24^{\circ} \mathrm{C}$. The aldehydes synthesis had reached its peak during the rapid fermentation, thereafter it began to go down. The studied yeast synthesized more aldehydes when the process took place at a lower temperature. For both strains the maximum was observed under the conditions $20^{\circ} \mathrm{C} / 4 \%$. The analysis of the obtained wines had confirmed that quantitatively Badachoni produced more total higher alcohols and the 24-6 more total aldehydes. In both strains within one temperature range, in all variants, with increasing the inoculum amount of yeast culture the studied metabolites ratio went up too.
\end{abstract}

Key words: Saccharomyces cerevisiae, alcoholic fermentation, wine, higher alcohols, aldehydes, neural network.

\footnotetext{
${ }^{1}$ Institute of Viticulture and Enology, Department of Vine Selection, Enology and Chemistry, 1 "Kala tepe"str., 5800 Pleven, Bulgaria;

2 University of Food Technologies, Department of Wine and Beer Technology, 26 “Maritsa” blvd., 4002 Plovdiv,Bulgaria;

Correspondence: Tatyana Yoncheva; email: t_ion@abv.bg.
} 


\section{Introduction}

One of the most important features of wines had been their aroma, formed by the content of a large number of volatile chemical components, with varying ratios. These compounds had different origins and underwent changes in the winemaking process. Some were derived from grapes, but most were formed during the alcoholic fermentation and wine aging [10], [18], [24].

Yeasts played a vital role in the production of wine. The alcoholic fermentation was traditionally carried out with Saccharomyces cerevisiae strains because of their high ethanol resistance. Their growth was supported by the existence of basic compounds such as fermentable sugars, amino acids, vitamins, minerals and oxygen. Yeast had different fermentative behavior, metabolism and technological characteristics and was largely responsible for the complexity of the chemical composition and sensory qualities of wines [17].

The higher alcohols and aldehydes were contained in traces in grapes and were synthesized mainly during the fermentation, as a result of yeast metabolism. Their quantity had been strongly influenced by some technological factors such as grape variety and composition, processing scheme, yeast species and strain, fermentation conditions - temperature, aeration, $\mathrm{pH}$, etc. [4], [20], [22], [25].

Higher alcohols might be produced in different ways, by various precursors, but mainly during the decomposition of sugars, in the oxidation or deamination of the respective amino acids [4], [19], [24]. Their synthesis might be regulated by using appropriate yeast strains and by directing their metabolism [16], [18]. The application of cold maceration had increased the amount of higher alcohols due to the extraction of more precursors from grape skins [16]. Usually the factors that accelerated the alcoholic fermentation (higher amount of yeast biomass, aeration, high temperature) had led to a raise in the amount of higher alcohols in the fermentation medium. Their ratio might go up with prolonged retention of wine on the yeast lees, as a result of autolysis, as well as a result of unwanted microbiological processes. During wine storage and processing, the higher alcohols ratio had dropped down due to oxidation to the relevant aldehydes or participation in ester formation reactions [6], [18], [24]. Their content varied widely from 150 to $600 \mathrm{mg} / \mathrm{l}$. The higher alcohols were involved in the formation of the wine's organoleptic characteristics, having a greater influence on the aroma and to a lesser extent on the taste. Usually their threshold ratios were higher than their amount, that's why they rarely caused an individual sensory effect [1], [4], [6], [20].

Aldehydes had been one of the most reactive groups of compounds in wine. Their representatives, as well as the products of the reactions in which they participated, had a significant influence on the organoleptic characteristics. During the alcoholic fermentation, the yeast synthesized over 20 aldehydes from various precursors - amino acids, the corresponding alcohols, sugars. Their content in wines depended on a number of technological factors. The species and strain of yeast causing the alcoholic fermentation had been essential [1], [14]. In the presence of more $\mathrm{SO}_{2}$ in the fermentation medium, more aldehydes 
would accumulate [6], [8], [14, 15], [23]. Their total amount varied from 10 to 200 $\mathrm{g} / \mathrm{l}$, with $90 \%$ being acetaldehyde [6], [13]. In the process of fermentation, its ratio increased and reached its peak during the exponential phase of yeast development, thereafter it began to decrease due to its involvement in the condensation processes and other reactions. The synthesis of acetaldehyde had been strongly influenced by the fermentation temperature as a greater amount formed at a higher fermentation temperature or $\mathrm{pH}$ [3], [23]. The main representative, acetaldehyde, had the smell of a green apple and had not always been a desirable component. In an amount of over $100 \mathrm{~g} / \mathrm{l}$ it gave the wine a shade of being oxidized or tasteless [1], [3], [6].

The objective of the study was to establish the influence of the technological factors, i.e. yeast strain, temperature and inoculum amount of yeast culture, on the higher alcohols and aldehydes' synthesis during the alcoholic fermentation and their content in the obtained wines.

\section{Material and Methods}

\subsection{Grapes Processing and Composition}

The experiments were carried out at the Institute of Viticulture and Enology (IVE) Pleven, with grapes of the local red variety Gamza, typical for the region of Pleven, Central Northern Bulgaria (the Danube plain). The grapes were harvested at suitable technological maturity (Table 1) and processed according to the classical technology for red wine production in the conditions of micro-vinification [26]. Each variant was crushed and strained off separately and by equal distribution of the clusters a uniformity of the raw material was ensured.

Chemical composition of grapes from Gamza variety Table 1

\begin{tabular}{|c|c|c|c|c|c|c|}
\hline \multicolumn{10}{|c|}{ Indicators } \\
\hline $\begin{array}{c}\text { Dry matter } \\
{[\%]}\end{array}$ & $\begin{array}{c}\text { Sugar } \\
{[\%]}\end{array}$ & $\begin{array}{c}\text { Glucose } \\
{[\mathrm{g} / \mathrm{l}]}\end{array}$ & $\begin{array}{c}\text { Fructose } \\
{[\mathrm{g} / \mathrm{I}]}\end{array}$ & $\begin{array}{c}\text { Titratable } \\
\text { acids }[\mathrm{g} / \mathrm{l}]\end{array}$ & $\begin{array}{c}\text { Glucoacidometric } \\
\text { index }\end{array}$ & $\mathbf{p H}$ \\
\hline 21.60 & 21.10 & 95.86 & 114.14 & 6.80 & 3.62 & 3.31 \\
\hline
\end{tabular}

The analyzed indicators were determined in accordance with the following methods: dry matter, \% - Abbe refractometer; sugar, \% - hydrometer of Dujardin; glucose and fructose, $\mathrm{g} / \mathrm{l}$ iodometric method; titratable acids, $\mathrm{g} / \mathrm{I}$ titration with $\mathrm{NaOH}$; glucoacidometric index - calculation method as the ratio of sugars, \%: titrable acids, $\mathrm{g} / \mathrm{l} ; \mathrm{pH}-\mathrm{pH}-$ meter [11].

\subsection{Alcoholic Fermentation and Synthesis of Higher Alcohols and Aldehydes}

The alcoholic fermentation occurred under the following conditions:

- Substrate - $4.0 \mathrm{~kg}$ of grape pomace, sulphated with $50 \mathrm{mg} / \mathrm{kg} \mathrm{SO}{ }_{2}$, with chemical composition (Table 1);

- Inoculum - 48-hour active yeast culture from Badachoni and 24-6 strains of Saccharomyces cerevisiae species, in quantity of $2 \%, 3 \%, 4 \%$ (the strains 
were provided from the yeast collection of the Department of Wine and Beer Technology, University of Food Technologies (UFT) - Plovdiv, Bulgaria);

- Temperature $-20^{\circ} \mathrm{C}, 24^{\circ} \mathrm{C}, 28^{\circ} \mathrm{C}$.

The course of the alcoholic fermentation was monitored on a daily basis through the dry matter change, measured with an Abbe refractometer to a constant value.

The rate in the change of the total higher alcohols and aldehydes in the course of the process was determined by recordings in the following stages: onset (day 1 ), rapid fermentation (day 5), quiet fermentation (day 10) and after the malolactic fermentation (day 20). For analyzing their content the following methods were used [11]:

-Total higher alcohols, mg/l - modified Komarowski-Felenberg method (based on the property of higher alcohols in sulfuric acid medium with $p$ dimethylaminobenzaldehyde to form color compound with maximum absorption at $\lambda 536 \mathrm{~nm}$ );

- Total aldehydes, $\mathrm{mg} / \mathrm{l}$ - bisulfite method (to the distilled wine sample was added a buffer solution with $\mathrm{pH} 7$ and $\mathrm{NaHSO}_{3} . \mathrm{HCl}$ and starch were added in 30 minutes, and the sample successively was titrated with $0.1 \mathrm{~N} \mathrm{I}_{2}$ to slightly blue color, with alkaline borate solution to slightly pink color and with $0.01 \mathrm{~N} \mathrm{I}_{2}$ to slightly blue color).

\subsection{Neural Networks}

The experimental results were modeled through neural networks of the Statistica 8 software package using a second order quasi-Newton algorithm describing the influence of time, fermentation temperature and inoculum amount of the yeast culture on the synthesis of total quantity of higher alcohols and aldehydes. For each model, the number of neurons in the input layer was 3 (temperature, amount of yeast culture, time) and 1 for the output layer. The number of neurons in the hidden layer was set to be changed from 3 to 15 . As a result, the network that gave the highest correlation ratio with the experimental data was chosen. The results were also presented in the form of surfaces describing the experimental data with high precision [5], [7], [21].

\subsection{Wine Chemical Composition}

The course and completion of the spontaneous malolactic fermentation were determined qualitatively by paper chromatography for organic acids.

After the completion of the alcoholic and malolactic fermentation all experimental wines were decanted and analyzed for the indicators [11]: alcohol, vol. \% (distillation method, DEE Distillation Unit with Densimat and Alcomat, Gibertini); sugars, g/l (Schoorl's method); total extract $\mathrm{g} / \mathrm{I}$ (DEE Distillation Unit with Densimat and Alcomat, Gibertini by density of the non-alcoholic sample), sugarfree extract, $\mathrm{g} / \mathrm{l}$ (calculation method of the difference between the total extract and the sugars); titratable acids, $\mathrm{g} / \mathrm{l}$ (titration with $\mathrm{NaOH}$ ); $\mathrm{pH}$ (pH-meter); total higher alcohols, $\mathrm{mg} / \mathrm{l}$ (modified Komarowski-Felenberg method); total aldehydes $\mathrm{mg} / \mathrm{l}$ (bisulphite method).

The presented experimental results were the arithmetic mean value of two similar samples. In the cases when a significant difference in the rates of the studied indicator was found, a third sample was made and the two closest values were taken into account. 


\section{Results and Discussions}

\subsection{Alcoholic Fermentation and} Synthesis of Higher Alcohols and Aldehydes

When monitoring the influence of the fermentation temperature and the inoculum amount of yeast culture on the time of the process occurring with the studied yeast strains, a similar change in the dry matter was observed. The investigated yeasts showed high fermentation activity, as the intensity at

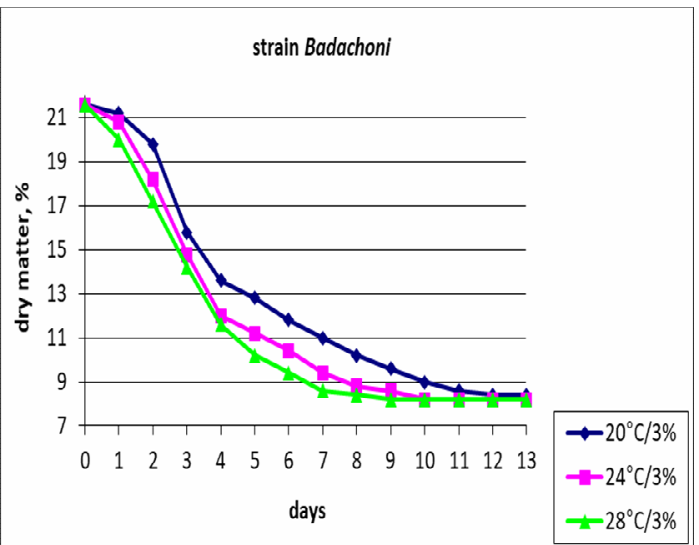

the onset of the alcoholic fermentation and the time of its completion were in proportional correlation with the technological factors. The Badachoni and the 24-6 strains revealed the highest activity at $28^{\circ} \mathrm{C}$. At $20^{\circ} \mathrm{C}$ the fermentation started and proceeded more slowly. With the increase of the inoculum $(2 \%, 3 \%, 4 \%)$, within one temperature range, the fermentation started and ended earlier, due to the greater number of active yeast cells in the medium (Figure 1).

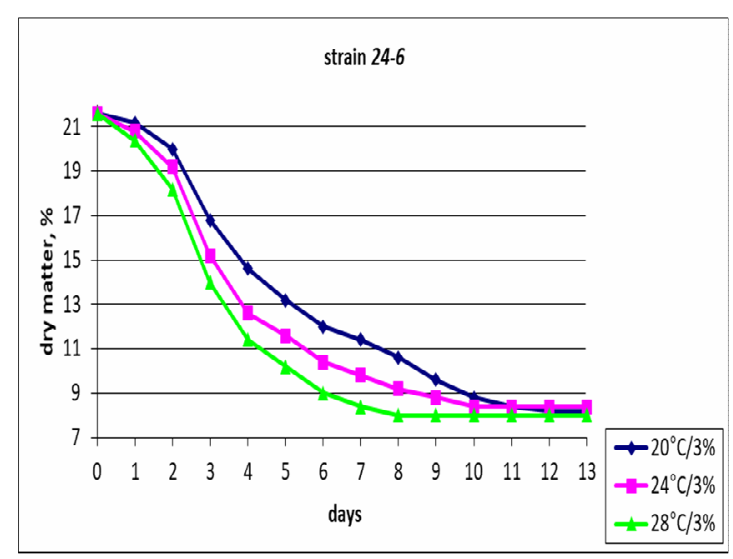

Fig. 1. Dynamics of the dry matter during the alcoholic fermentation with the studied strains

To establish the impact of the fermentation factors, i.e. temperature and inoculum amount of yeast culture, on the synthesis of total higher alcohols and total aldehydes by the studied strains, in the course of the alcoholic fermentation (days $1,5,10$ and 20) their change was traced. For all variants, neural networks had been prepared, modeling the processes and characterized by high accuracy of description of the experimental data. The results demonstrated the stronger effect of the temperature compared to the inoculum of yeast culture that was similar and relatively weaker.

Higher alcohols had been synthesized mainly during the alcoholic fermentation by the yeast as a result of the carbohydrate metabolism. Their total amount increased during the process, due to the greater number of active cells in the medium and the presence of substrates and precursors that determined their formation - mainly sugars and amino acids. Then in the period of quiet and malolactic fermentation their quantity changed insignificantly.

Under the conditions of the experiment, the Badachoni and the 24-6 strains showed a common trend in the synthesis of this metabolite under the influence of the amount of the yeast culture factor. In all experimental variants, as the percentage of inoculum was increased, so 
did their ratio. Differences between both strains were observed for the impact of the temperature as a factor. The obtained results describing the changes of the total higher alcohols concentration in the fermentation medium are presented in Figures 2 and 3.

The strain Badachoni produced the greatest amount of higher alcohols when the fermentation took place at a temperature of $28^{\circ} \mathrm{C}$. That trend stood out at the beginning of the process and continued to its end. In the experimental variants, their content during the rapid fermentation varied from $59.00\left(20^{\circ} \mathrm{C} / 2 \%\right)$ to $189.00 \mathrm{mg} / \mathrm{l}\left(28^{\circ} \mathrm{C} / 4 \%\right)$, and at the end of the process - from $128.00\left(20^{\circ} \mathrm{C} / 2 \%\right)$ to $212.00 \mathrm{mg} / \mathrm{l}\left(28^{\circ} \mathrm{C} / 4 \%\right)$.

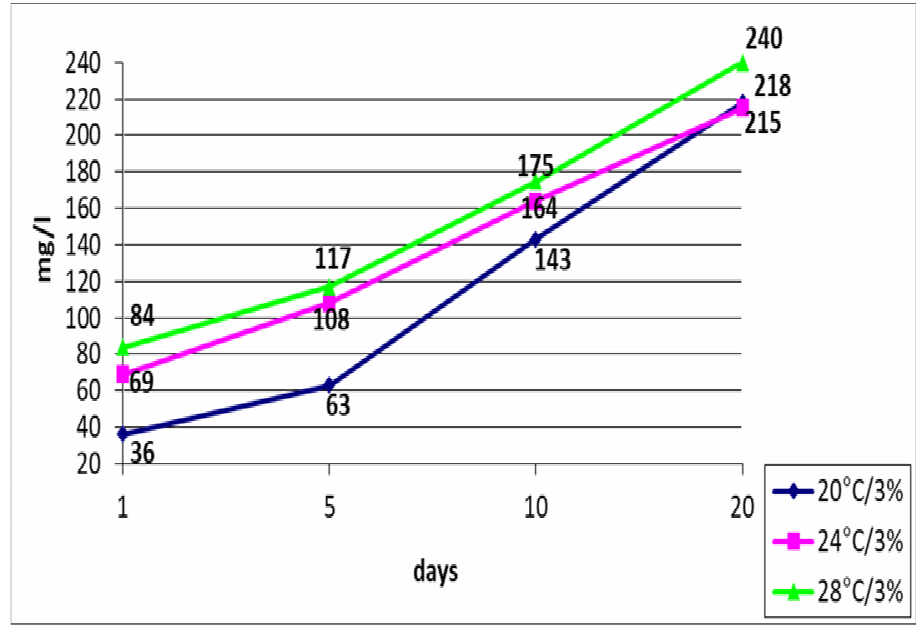

a)

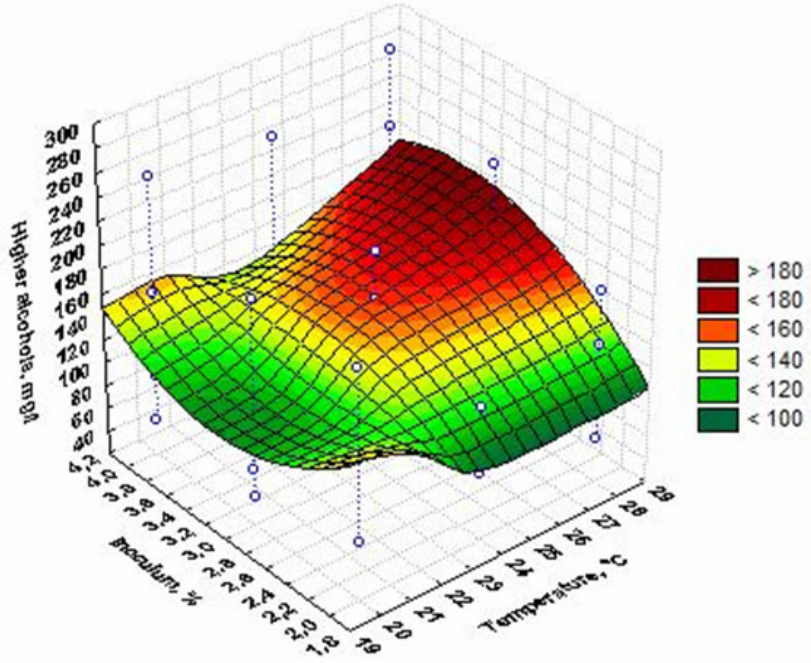

b)

Fig. 2. Change in the total higher alcohols ratio during the alcoholic fermentation with Badachoni strain: a) higher alcohols synthesis at different fermentation temperatures; b) surface describing the difference in the higher alcohols ratio under the influence of the studied technological factors 


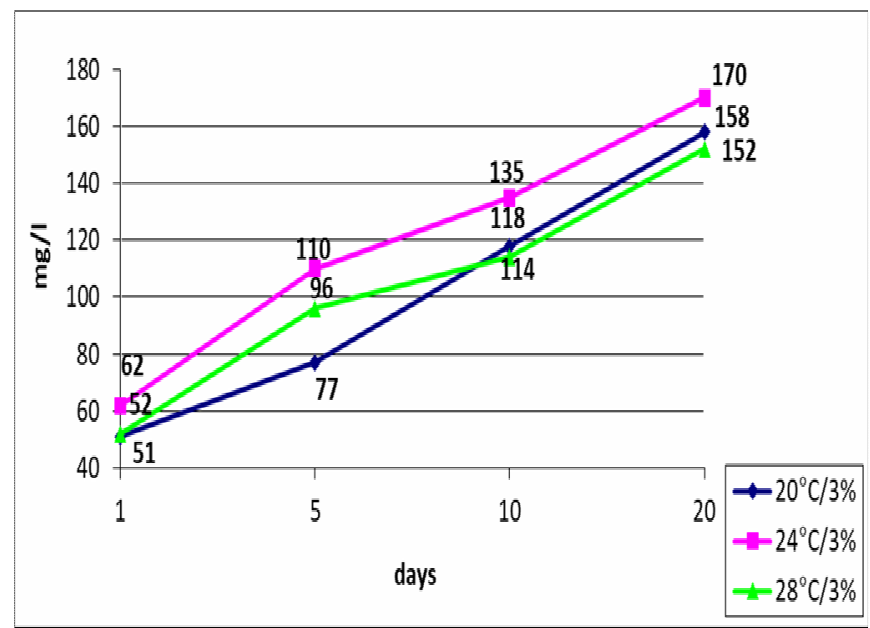

a)

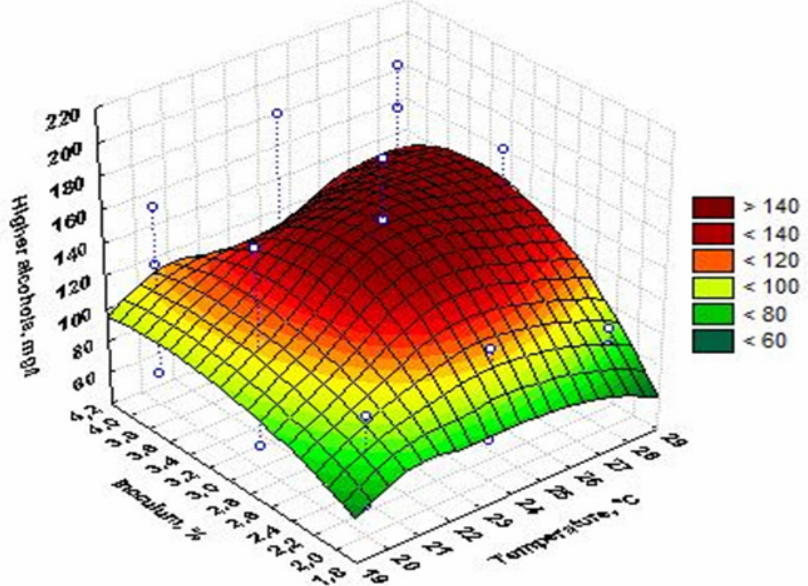

b)

Fig. 3. Change in the total higher alcohols ratio during the alcoholic fermentation with 24-6 strain: a) higher alcohols synthesis at different fermentation temperatures;

b) surface describing the difference in the higher alcohols ratio under the influence of the studied technological factors

The yeast 24-6 quantitatively produced less higher alcohols than the Badachoni, as the strain synthesized most of them during the alcoholic fermentation at a temperature of $24^{\circ} \mathrm{C}$. In the variants, their content during the rapid stage varied from $45.00\left(20^{\circ} \mathrm{C} / 2 \%\right)$ to $125.00 \mathrm{mg} / \mathrm{l}\left(28^{\circ} \mathrm{C} / 4 \%\right)$, and at the end of the process - from $128.00\left(20^{\circ} \mathrm{C} / 2 \%\right)$ to $185.00 \mathrm{mg} / \mathrm{l}$ $\left(24^{\circ} \mathrm{C} / 4 \%\right)$. These results were similar to those found by other authors, namely that in total most higher alcohols were obtained by fermentation at a temperature of $20-25^{\circ} \mathrm{C}[1,2]$, [9], [12].

During the alcoholic fermentation, the aldehydes were synthesized from different precursors, so their ratio depended on the grape composition and the fermentation conditions. That determined the different ability of the yeast to produce this metabolite. The total aldehydes synthesis exhibited a general 
trend in the course of the fermentation. At the beginning of the process, their amount increased rapidly, reached a peak during the rapid stage (day 5), and then started to decrease. Since the main part of the aldehydes was acetaldehyde, that was due to its reduction to ethanol or its participation in the condensation processes. Under the conditions of the experiment, a tendency was observed for the studied strains to synthesize the maximum amount of aldehydes when the fermentation occurred at a lower temperature. All variants with higher percentage of inoculum had a higher concentration. The results describing the total aldehydes change in the fermentation medium are presented in Figures 4 and 5 .

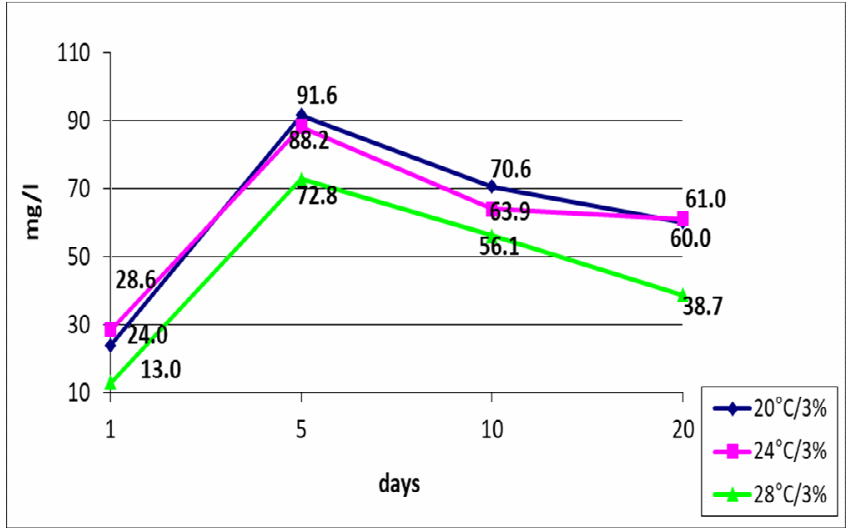

a)

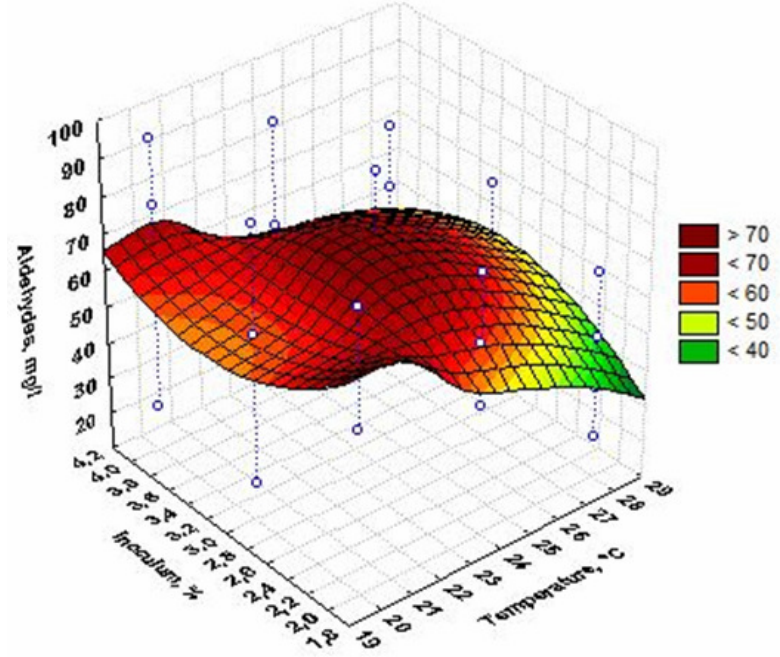

b)

Fig. 4. Change in the total aldehydes ratio during the alcoholic fermentation with Badachoni strain:

a) aldehydes synthesis at different fermentation temperatures;

b) surface describing the difference in the aldehydes ratio under the influence of the studied technological factors 


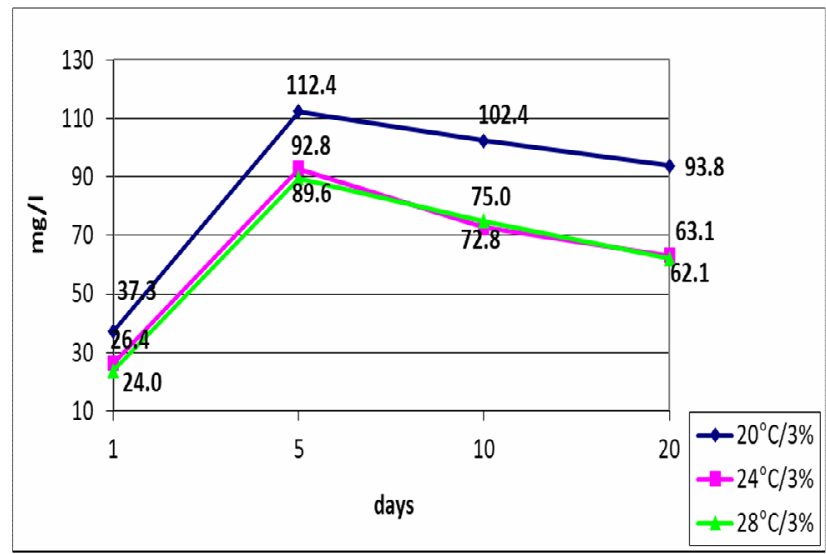

a)

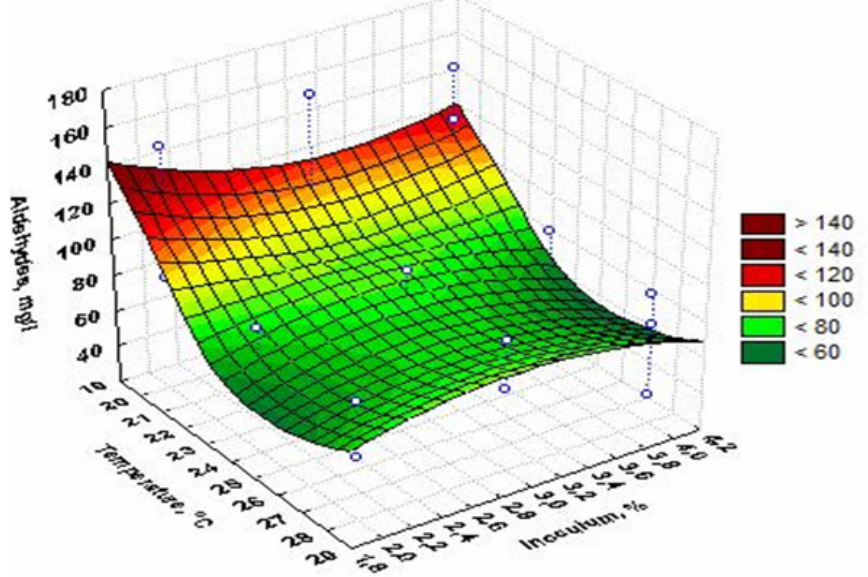

b)

Fig. 5. Change in the total aldehydes ratio during the alcoholic fermentation with 24-6 strain: a) aldehydes synthesis at different fermentation temperatures; $b$ ) surface describing the difference in the aldehydes ratio under the influence of the studied technological factors

The strain Badachoni synthesized a greater amount of total aldehydes during the fermentation at a temperature of $20^{\circ} \mathrm{C}$ and $24^{\circ} \mathrm{C}$. The peak was recorded during the rapid phase at $20^{\circ} \mathrm{C} / 4 \%(96.00 \mathrm{mg} / \mathrm{l})$, and the minimum - in the variant $28^{\circ} \mathrm{C} / 2$ $\%(67.00 \mathrm{mg} / \mathrm{l})$.

The strain $24-6$ produced a significantly higher amount of aldehydes during the fermentation at $20^{\circ} \mathrm{C}$, as compared to $24^{\circ} \mathrm{C}$ and $28^{\circ} \mathrm{C}$. During the rapid phase, at a temperature of $20^{\circ} \mathrm{C}$ the strain synthesized from 145.40 to $172.40 \mathrm{mg} / \mathrm{l}$ total aldehydes. The minimum was registered at $28^{\circ} \mathrm{C}$, from 85.00 to 89.60 $\mathrm{mg} / \mathrm{l}$, respectively.

In both strains, within one temperature range, when increasing the amount of yeast culture, the content of total aldehydes went up, due to the greater number of active yeast cells in the medium. 


\subsection{Wine Chemical Composition}

The chemical composition of the obtained experimental Gamza wines in regard to the main chemical indicators and the content of total higher alcohols and total aldehydes are presented in Tables 2 and 3.

Table 2

Chemical composition of the experimental Gamza wines fermented with "Badachoni" strain

\begin{tabular}{|c|c|c|c|c|c|c|c|c|c|}
\hline Variants & \multicolumn{3}{|c|}{$\mathbf{2 0}^{\mathbf{0}} \mathbf{C}$} & \multicolumn{3}{c|}{$\mathbf{2 4}^{\circ} \mathbf{C}$} & \multicolumn{3}{c|}{$\mathbf{2 8}^{\circ} \mathbf{C}$} \\
\cline { 2 - 10 } Indicators & $\mathbf{2 \%}$ & $\mathbf{3 \%}$ & $\mathbf{4 \%}$ & $\mathbf{2 \%}$ & $\mathbf{3 \%}$ & $\mathbf{4 \%}$ & $\mathbf{2 \%}$ & $\mathbf{3 \%}$ & $\mathbf{4 \%}$ \\
\hline Alcohol [vol. \%] & 12.57 & 12.60 & 12.65 & 12.42 & 12.50 & 12.67 & 12.62 & 12.70 & 12.70 \\
\hline Sugar [g/l] & 1.37 & 1.54 & 1.54 & 1.47 & 2.01 & 1.78 & 1.81 & 1.40 & 1.54 \\
\hline $\begin{array}{c}\text { Sugarfree extract } \\
{[\mathrm{g} / \mathrm{l}]}\end{array}$ & 20.33 & 20.26 & 20.96 & 20.63 & 20.79 & 21.02 & 21.18 & 21.00 & 21.27 \\
\hline $\begin{array}{c}\text { Titratable acids } \\
{[\mathrm{g} / \mathrm{l}]}\end{array}$ & 5.93 & 6.00 & 5.93 & 5.78 & 5.55 & 5.25 & 5.70 & 5.85 & 5.48 \\
\hline $\mathrm{pH}$ & 3.25 & 3.18 & 3.19 & 3.17 & 3.23 & 3.26 & 3.22 & 3.21 & 3.25 \\
\hline $\begin{array}{c}\text { Total aldehydes } \\
{[\mathrm{mg} / \mathrm{l}]}\end{array}$ & 56.98 & 60.03 & 65.08 & 55.96 & 61.05 & 63.08 & 30.53 & 38.66 & 41.22 \\
\hline $\begin{array}{c}\text { Total higher } \\
\text { alcohols [mg/l] }\end{array}$ & 212.00 & 218.00 & 258.00 & 198.00 & 215.00 & 232.00 & 190.00 & 240.00 & 282.00 \\
\hline
\end{tabular}

Table 3

Chemical composition of the experimental Gamza wines fermented with 24-6 strain

\begin{tabular}{|c|c|c|c|c|c|c|c|c|c|}
\hline \multirow[b]{2}{*}{$\begin{array}{l}\text { Variants } \\
\text { Indicators }\end{array}$} & \multicolumn{3}{|c|}{$20^{\circ} \mathrm{C}$} & \multicolumn{3}{|c|}{$24^{\circ} \mathrm{C}$} & \multicolumn{3}{|c|}{$28^{\circ} \mathrm{C}$} \\
\hline & $2 \%$ & $3 \%$ & $4 \%$ & $2 \%$ & $3 \%$ & $4 \%$ & $2 \%$ & $3 \%$ & $4 \%$ \\
\hline $\begin{array}{c}\text { Alcohol [vol. } \\
\%]\end{array}$ & 12.38 & 12.26 & 12.58 & 12.23 & 12.51 & 12.48 & 12.53 & 12.58 & 12.57 \\
\hline Sugar $[\mathrm{g} / \mathrm{l}]$ & 1.74 & 1.61 & 1.54 & 1.71 & 1.74 & 1.50 & 1.74 & 1.57 & 1.88 \\
\hline $\begin{array}{l}\text { Sugarfree } \\
\text { extract }[\mathrm{g} / \mathrm{l}]\end{array}$ & 20.06 & 20.00 & 20.16 & 20.29 & 20.26 & 20.70 & 20.96 & 21.03 & 21.00 \\
\hline $\begin{array}{l}\text { Titratable } \\
\text { acids }[\mathrm{g} / \mathrm{l}]\end{array}$ & 5.73 & 5.40 & 5.40 & 5.10 & 5.30 & 5.85 & 5.78 & 5.78 & 5.85 \\
\hline $\mathrm{pH}$ & 3.27 & 3.19 & 3.22 & 3.21 & 3.23 & 3.17 & 3.19 & 3.19 & 3.15 \\
\hline $\begin{array}{c}\text { Total } \\
\text { aldehydes } \\
{[\mathrm{mg} / \mathrm{l}]}\end{array}$ & 82.42 & 93.78 & 99.78 & 59.02 & 63.08 & 63.50 & 56.98 & 62.07 & 63.82 \\
\hline $\begin{array}{c}\text { Total higher } \\
\text { alcohols } \\
{[\mathrm{mg} / \mathrm{l}]}\end{array}$ & 138.00 & 150.00 & 170.00 & 158.00 & 170.00 & 218.00 & 138.00 & 152.00 & 216.00 \\
\hline
\end{tabular}

The amount of residual sugars in the variants confirmed the complete occurrence of the alcoholic fermentation. Badachoni strain showed a better alcohol- forming ability, proven by the higher alcohol content of its samples. The differences in alcohol between the variants of one strain were insignificant. 
The amount of sugar-free extract in the experimental wines was in accordance with the specifics of the variety. Its content in the variants of both strains was close and proportional to the temperature rise. The samples fermented at $28^{\circ} \mathrm{C}$ had the highest rates because the higher temperature favoured the extraction of a larger number of extract substances from the grapes during fermentation. There were no significant differences in the content of titratable acids in the wines obtained with the two strains. From the samples of Badachoni strain, those with higher acidity were obtained at $20^{\circ} \mathrm{C}$, and from those of strain $24-6$ - at $28^{\circ} \mathrm{C}$.

The conditions for the alcoholic fermentation significantly affected the synthesis of the metabolites by the yeast. The trend established in the course of the alcoholic fermentation was preserved in the obtained wines.

In the experimental wines fermented with Badachoni strain, the greatest amount of higher alcohols was analyzed in the samples obtained at a temperature of $28^{\circ} \mathrm{C}$. Their amount in these variants was within the range of 190.00 to $282.00 \mathrm{mg} / \mathrm{l}$. The samples of the strain fermented at 20 and $24^{\circ} \mathrm{C}$ had a lower content of the metabolite. Contrary to Badachoni, from the samples of the 8-24 strain, those obtained at a fermentation temperature of $24^{\circ} \mathrm{C}$ were characterized by a higher ratio of higher alcohols - from 158.00 to $218.00 \mathrm{mg} / \mathrm{l}$. The variants of this strain that fermented at $20^{\circ} \mathrm{C}$ had the lowest metabolite content (138.00 to 170.00 $\mathrm{mg} / \mathrm{l})$. The analysis of the experimental wines revealed that, in total, Badachoni strain synthesized a greater amount of higher alcohols than the 24-6. Within one temperature range, the samples which fermented with a higher ratio of inoculum contained more of the studied metabolite.

The total aldehydes content in the wines of Badachoni strain was in the range of 30.53 to $65.08 \mathrm{mg} / \mathrm{l}$. The maximum amount was reported in the variant obtained at $20^{\circ} \mathrm{C} / 4 \%$. In the samples fermented at a temperature of $20^{\circ} \mathrm{C}$ and $24^{\circ} \mathrm{C}$, their ratio was significantly higher than in the variants obtained at $28^{\circ} \mathrm{C}$. The strain 24-6 quantitatively produced more total aldehydes as compared to Badachoni. Their content in the experimental samples varied from 56.98 to $99.78 \mathrm{mg} / \mathrm{l}$. The maximum amount was analyzed in the variants fermented at a temperature of $20^{\circ} \mathrm{C}$ (from 82.42 to 99.78 $\mathrm{mg} / \mathrm{l})$, while in those obtained at $24^{\circ} \mathrm{C}$ and $28^{\circ} \mathrm{C}$, the ratio of the studied metabolite was similar and lower. At the same temperature, the samples fermented with a higher percentage of yeast culture contained more total aldehydes.

\section{Conclusions}

The following conclusions could be drawn from the study:

- The studied yeasts exhibited high fermentation activity, as the intensity at the onset of the alcoholic fermentation and at the time of its completion were in proportional correlation with the technological factors - temperature and inoculum amount of yeast culture. Badachoni and 24-6 strains revealed the highest activity at $28^{\circ} \mathrm{C}$;

- The prepared neural networks, modeling the processes of the higher alcohols and aldehydes synthesis, were characterized by a high accuracy of the description of the experimental data. The results showed a stronger effect of 
the temperature than of the amount of yeast culture, which was similar and relatively weaker;

-The total amount of higher alcohols increased during the course of the alcoholic fermentation. Badachoni strain exhibited a better ability to synthesize this metabolite than the 24-6 strain. Badachoni produced the most higher alcohols when the process occurred at a temperature of $28^{\circ} \mathrm{C}$, and the $24-6$ strain at $24^{\circ} \mathrm{C}$;

-The total aldehydes synthesis showed a general trend in the course of the fermentation - it reached its peak during the rapid stage, then it began to decrease. Under the conditions of the experiment, the studied yeast formed more aldehydes when the process occurred at a lower temperature. For both strains, the maximum in the synthesis was recorded at $20^{\circ} \mathrm{C} / 4 \%$;

-With both strains, within one temperature range, in the variants with an increased inoculum amount of yeast culture, the ratio of the total higher alcohols and total aldehydes went up too;

-The analysis of the experimental wines obtained with both strains confirmed that quantitatively Badachoni strain synthesized more total higher alcohols and the 24-6 strain synthesized more total aldehydes.

\section{References}

1. Bambalov G., 1981. Microbiology of wine production (in Bulgarian). Publishing House "Hristo G. Danov", Plovdiv, Bulgaria, pp. 116-130.

2. Beltran i Casellas G., 2005. Effect of low temperature fermentation and nitrogen content on wine yeast metabolism. PhD Thesis, Universitat Rovira i Virgili, Facultat d'Enologia, Department de Bioquimica i Biotechnologia, Tarragona, Spain. Available at: https://www.tdx.cat/bitstream/handl e/10803/8651/Tesis_G.Beltran.pdf?se quence $=1 \&$ isAllowed $=y$. Accessed on: August 15, 2021.

3. Byrne S.P Howell G., 2017. Acetaldehyde - how to limit its formation during fermentation. In: Grapegrower and Winemaker, vol. 637, pp. 68-69.

4. Cameleyre M., Lytra G., Tempere S. et al. 2015. Olfactory impact of higher alcohols on red wine fruity ester aroma expression in model solution. In: Journal of Agricultural and Food Chemistry, vol. 63(44), pp. 9777-9788. doi: 10.1021/acs.jafc.5b03489.

5. Chen L., Nguang S., Chen X., 2006. Modelling and optimization of biotechnological processes. Artificial Intelligence Approaches, Book series Studies in Computational Intelligence, vol. 15, Springer, Berlin.

6. Chobanova D., 2012. Enology. Part I: Composition of wine (in Bulgarian). Academic Press of University of the Food Technologies, Plovdiv, Bulgaria, pp. 9-23, 169-181.

7. Cichoski A., Unbehauen R., 1993. Neural networks for optimization and signal processing. USA, John Wiley \& Sons, New York, USA, 544 p.

8. Frivik S., Ebeler S., 2003. Influence of sulfur dioxide on the formation of aldehydes in white wine. In: American Journal of Enology and Viticulture, vol. 54(1), pp. 31-38.

9. Hronsky V., Kovacsova A., Dömeny Z. et al., 1999. Vplyv upravy muštu a pôsobenie teploty fermentacie na 
obsah aminokyselin a prchavych latok vo vine. In: Vinohrad, vol. XXXVII(4), pp. 1-4.

10. Ilc T., Werck-Reichhart D., Navrot N., 2016. Meta-analysis of the core aroma components of grape and wine aroma. In: Frontiers in Plant Science, vol. 7, 1472. doi: 10.3389/fpls.2016.01472.

11. Ivanov T., Gerov S., Yankov A. et al., 1979. Practicum in wine technology (in Bulgarian). Publishing House "Hristo G. Danov", Plovdiv, Bulgaria, pp. 82-84, 304-305.

12. Kolarik M., Hatrikova Z., Hrivňak J., et al., 2004. Čiste kultury kvasiniek a ich vplyv na kvalitu a aromu vina. In: Vinohrad, vol. 42(6), pp. 5-6.

13. Lee A., 2020. Metabolic by-products in alcohol fermentation of wine yeast. Available at: https://en.angelyeast.com/blog/distill ed-spirits-and-biofuels/metabolic-byproductd-in-alcohol-fermentation-ofwine-yeast.html. Accessed on: August 15, 2021.

14. Li E., Orduña R.M., 2017. Acetaldehyde kinetics of enological yeast during alcoholic fermentation in grape must. In: Journal of Industrial Microbiology \& Biotechnology, vol. 44(2), pp. 229-236. doi: 10.1007/s10295-016-1879-7.

15. Li E., Orduña R.M., 2020. Acetaldehyde metabolism in industrian strains of Saccharomyces cereviciae inhibited by $\mathrm{SO}_{2}$ and cooling during alcoholic fermentaion. In: OENO One, vol. 54(2), pp. 351-358. doi: 10.20870/oenoone.2020.54.2.2391.

16. Liu P.T., Lu L., Duan C.Q. et al., 2016. The contribution of indigenous nonSaccharomyces wine yeast to improved aromatic quality of
Cabernet Sauvignon wines by spontaneous fermentation. In: LWT Food Science and Technology, vol. 71, pp. 356-363. doi: 10.1016/j.Iwt.2016.04.031.

17. Maicas S., 2020. The role of yeasts in fermentation processes. In: Microorganisms, vol. 8(8), 1142. doi: 10.3390/microorganisms8081142.

18. Mendes I., Sanchez I., Franco-Duarte R. et al., 2017. Integrating transcriptomics and metabolomics for the analysis of the aroma profiles of Saccharomyces cerevisiae strains from diverse origins. In: BMC Genomics, vol. 18, pp. 455-464. doi: 10.1186/s12864017-3816-1.

19. Mina M., Tsaltas D., 2017. Contribution of yeast in wine aroma and flavour. In: INTECH, vol. 5, pp. 117-134. doi: 10.5772/intechopen.70656.

20. Nan L., Guo M., Chen S. et al., 2018. Effect of peduncle on aroma of Cabernet Sauvignon dry red wine. In: Conference Proceedings of the International Conference on Biotechnology and Bioengineering, $8^{\text {th }}$ ICBB, pp. 020008-1 - 020008-12. doi: 10.1063/1.5092386.

21. Nicoletti M., Jain L., 2009. Studies in computational intelligence. Book: Computational Intelligence Techniques for Bioprocess Modelling, Supervision and Control, vol. 218, Springer Berlin/Heidelberg.

22. Pons A., Allamy L., Schüttler A. et al., 2017. What is the expected impact of climate change on wine aroma compounds and their precursors in grape? In: OENO One, vol. 51(2), pp. 141-146. doi: 10.20870/oenoone.2017.51.2.1868. 
23. Romano P., Suzzi G., Turbanti L. et al., 1994. Acetaldehyde production in Saccharomyces cerevisiae wine yeast. In: FEMS Microbiology Letters, vol. 118(3), pp. 213-218. doi: 10.1111/j.1574-6968.1994.tb06830.x.

24. Styger G., Prior B., Bauer F.F., 2011. Wine flavour and aroma. In: Journal of Industrial Microbiology and Biotechnology, vol. 38(9), pp. 1145-1159. doi: 10.1007/s10295011-1018-4.
25. Vilanova M., Cortes S., Santiago J.L. et al., 2007. Aromatic compounds in wines produced during fermentation: effect of three red cultivars. In: International Journal of Food Properties, vol. 10(4), pp. 867-875. doi: 10.1080/10942910601161615.

26. Yankov A., 1992. Wine making technology (in Bulgarian). Publishing House "Zemizdat", Sofia, Bulgaria, pp. 141-181. 